\title{
Secular Changes in Child Height in Japan and South Korea: Consumption of Animal Proteins and "Essential Nutrients"
}

\author{
Hiroshi Mori \\ Senshu University, Chiyoda, Tokyo, Japan \\ Email: the0033@isc.senshu-u.ac.jp
}

How to cite this paper: Mori, H. (2018) Secular Changes in Child Height in Japan and South Korea: Consumption of Animal Proteins and "Essential Nutrients". Food and Nutrition Sciences, 9, 1458-1471. https://doi.org/10.4236/fns.2018.912106

Received: November 16, 2018

Accepted: December 26, 2018

Published: December 29, 2018

Copyright $\odot 2018$ by author and Scientific Research Publishing Inc. This work is licensed under the Creative Commons Attribution International License (CC BY 4.0).

http://creativecommons.org/licenses/by/4.0/

Open Access

\begin{abstract}
Child height in Japan and South Korea increased dramatically over the past half century. At age 17 - 18 years, male students in Japan were $2 \mathrm{~cm}$ taller in the 1960s through 1970s, still barely taller in the 1980s than S. Korean students, but by the early 1990s they ceased to grow any taller in height, whereas their Korean peers kept increasing in height to overtake their Japanese peers by $3 \mathrm{~cm}$ in the mid-2000s. Economic growth was rapid in both countries, but S. Korea some two decades behind Japan. Per capita GDP in Japan was four times that in S. Korea in the mid-1980s and twice in the early-2000s. Food consumption increased conspicuously in both countries, with per capita net supply of animal products in Japan noticeably exceeding that in S. Korea in the early-2000s. However, per capita total caloric intake has been a few hundred kcal/day greater in S. Korea than in Japan since the end of 1970s, mainly from cereals. In particular, S. Koreans have consumed nearly twice as many vegetables as Japanese after the early 1980s. What may deserve attention is that Japanese youth, as compared to their older generations, drastically reduced their consumption of fruit and vegetables in the mid-1970s, whereas their S. Korean counterparts have maintained their consumption of these produce. These contrasts in food consumption patterns may have contributed to the differences in child height development in the two countries.
\end{abstract}

\section{Keywords}

Child Height, Animal Proteins, Fruit and Vegetables, Japan, South Korea

\section{Introduction}

National income, which enables people to purchase animal proteins, is regarded as a key determinant of adult heights [1] [2]. Japan and South Korea made rapid 
economic progress since the end of WW II, with S. Korea some two decades behind Japan due to the Korean War (1950-53) which devastated the country. Per capita GDP (in 2010 U.S. Dollars) in Japan increased from $\$ 8608$ in 1960, to $\$ 25,489$ in 1980 , and eventually to $\$ 42,170$ in 2000 . That in S. Korea also increased steadily, but remained considerably behind Japan, at $\$ 944, \$ 3700$, and $\$ 15,104$ over the corresponding period [3]. Accordingly, per capita daily caloric intake from animal products increased from $251 \mathrm{kcal}$ in 1961 to $537 \mathrm{kcal}$ in 1980 and $604 \mathrm{kcal}$ in 2000 in Japan, whereas that in S. Korea also increased from 56 $\mathrm{kcal}$, to $212 \mathrm{kcal}$, and eventually to $447 \mathrm{kcal}$ over the same period [4]. As is shown in greater details in Table 2 and Table 3, Japan's per capita intake of animal products was nearly twice as large as that in S. Korea in 1990, for example.

Based on national school health examinations conducted with similar methods both in Japan and S. Korea [5] [6], school boys at age 17 - 18 years in Japan were $166 \mathrm{~cm}$ in mean height in the early 1960s, $2-3 \mathrm{~cm}$ taller than their Korean peers, $170 \mathrm{~cm}$ in the 1980s, $1 \mathrm{~cm}$ taller than in Korea, but ceased to grow taller in height around 1990. Their Korean pees kept growing taller in height, overtaking Japanese boys by $3 \mathrm{~cm}$ in the mid-2000s, as shown in greater detail in Table 1.

Intakes of animal proteins alone likely cannot explain the differences in child height development between the two countries over the past half century from 1960 to 2010. A genetic difference between Japanese and Korean population, however, is not easy to establish. The observed differences in child height development between Japan and S. Korea do not appear to be greater than those observed between different regions in the same country [7] [8]. Also, [9] "Growth status of Korean schoolchildren in Japan", states that Korean children born and raised in Japan are very similar, in height and weight by age, to Japanese children, based on school health surveys conducted in Tokyo and Osaka in the end of the 1970s and found taller in height and heavier in weight than their counterparts in S. Korea at the same time.

\section{Data}

\subsection{Child Height in Japan and South Korea}

School Health Examination Statistical Surveys [5] [6] ${ }^{1}$, which provide stature by age from $1^{\text {st }}$ graders in elementary school (6 years old $\left.{ }^{2}\right)$ to senior students in high school (17 years old ${ }^{2}$ ) have been conducted by the Ministry of Education every year since 1900 in Japan, except for a few years during WW II. Similar government surveys have been conducted in S. Korea since 1960. In view of the fact that the ratios of girls enrolled in high school for higher education in the 1960s

${ }^{1}$ In our previous studies, the data provided in [17] were used, which furnish child height by age from 1 to 20 years, in 1965, 1975, 1984, 1997, and 2005 in S. Korea. Accordingly, the similar data in the same years, $1965,1975,1984,1997$, and 2005 , based on [18], were employed.

${ }^{2}$ Depending on the month when the school surveys conducted, actual age of $1^{\text {st }}$ graders in elementary school was 6 years + some months old. 
and 1970s were substantially lower in S. Korea than in Japan [10], there is a possibility that statistics pertaining to mean height of girls in high schools in

Table 1. Secular changes in mean height of Jp. and Kr. school boys by age, from 1960 to 2010.

(a)

\begin{tabular}{ccccccccccccc}
\hline \multicolumn{10}{c}{ Mean height of Jp. school boys: 3 year moving averages (cm) } \\
\hline Age/year & 1960 & 1965 & 1970 & 1975 & 1980 & 1985 & 1990 & 1995 & 2000 & 2005 & 2010 \\
\hline 6 & 111.9 & 113.4 & 114.5 & 115.2 & 115.7 & 116.4 & 116.8 & 116.8 & 116.7 & 116.7 & 116.7 \\
7 & 117.2 & 118.8 & 120.0 & 120.8 & 121.3 & 122.1 & 122.5 & 122.6 & 122.4 & 122.5 & 122.6 \\
8 & 122.2 & 124.0 & 125.4 & 126.3 & 126.8 & 127.5 & 128.0 & 128.1 & 128.1 & 128.2 & 128.2 \\
9 & 127.0 & 128.8 & 130.3 & 131.4 & 132.0 & 132.7 & 133.3 & 133.5 & 133.5 & 133.6 & 133.5 \\
10 & 131.8 & 133.6 & 135.2 & 136.5 & 137.2 & 137.7 & 138.5 & 138.9 & 139.0 & 138.9 & 138.8 \\
11 & 136.5 & 138.6 & 140.4 & 141.9 & 142.8 & 143.3 & 144.4 & 144.9 & 145.3 & 145.1 & 145.0 \\
12 & 142.1 & 144.7 & 147.0 & 148.6 & 149.5 & 150.1 & 151.5 & 152.0 & 152.8 & 152.6 & 152.4 \\
13 & 148.7 & 151.8 & 154.0 & 156.0 & 157.1 & 157.6 & 158.9 & 159.5 & 160.1 & 159.9 & 159.7 \\
14 & 155.3 & 158.2 & 160.5 & 162.2 & 163.3 & 163.8 & 164.6 & 165.1 & 165.5 & 165.3 & 165.1 \\
15 & 161.5 & 163.5 & 164.7 & 166.1 & 167.0 & 167.5 & 167.9 & 168.4 & 168.6 & 168.4 & 168.3 \\
16 & 163.8 & 165.7 & 166.9 & 167.9 & 168.8 & 169.3 & 169.6 & 170.1 & 170.1 & 170.0 & 169.9 \\
17 & 165.1 & 166.7 & 167.9 & 168.8 & 169.6 & 170.2 & 170.5 & 170.9 & 170.9 & 170.8 & 170.7 \\
\hline
\end{tabular}

Notes: 1965 = average (1964: 1966), for example. Sources: [5].

(b)

\begin{tabular}{ccccccccccccc}
\hline \multicolumn{10}{c}{ Mean height of Kr. school boys: 3 year moving averages $(\mathrm{cm})$} \\
\hline Age/year & 1960 & 1965 & 1970 & 1975 & 1980 & 1985 & 1990 & 1995 & 2000 & 2005 & 2010 \\
\hline 6 & 111.0 & 111.9 & 112.9 & 114.1 & 116.4 & 116.7 & 117.7 & 119.0 & 120.2 & 121.0 & 121.8 \\
7 & 114.9 & 115.2 & 117.6 & 119.7 & 121.6 & 122.5 & 123.0 & 124.7 & 125.9 & 126.8 & 127.7 \\
8 & 119.0 & 119.3 & 121.5 & 123.8 & 126.6 & 127.5 & 128.3 & 130.0 & 131.2 & 132.2 & 133.2 \\
9 & 123.5 & 123.4 & 126.0 & 128.6 & 131.4 & 133.7 & 133.3 & 135.0 & 136.5 & 137.9 & 138.5 \\
10 & 128.0 & 127.5 & 130.3 & 133.2 & 135.6 & 137.2 & 138.3 & 140.0 & 141.9 & 143.1 & 143.9 \\
11 & 131.6 & 131.4 & 134.5 & 137.4 & 140.7 & 142.1 & 143.7 & 145.7 & 147.9 & 149.4 & 150.4 \\
12 & 140.3 & 141.8 & 143.7 & 144.4 & 146.3 & 148.2 & 149.7 & 152.0 & 154.8 & 156.9 & 158.0 \\
13 & 144.5 & 145.3 & 148.1 & 150.4 & 152.7 & 154.8 & 156.0 & 159.0 & 161.8 & 163.6 & 164.4 \\
14 & 149.5 & 150.1 & 152.3 & 155.9 & 159.4 & 161.0 & 162.3 & 164.7 & 167.0 & 168.3 & 169.0 \\
15 & 155.6 & 159.0 & 160.9 & 163.7 & 164.4 & 165.5 & 166.3 & 168.3 & 170.5 & 171.6 & 171.8 \\
16 & 161.2 & 161.9 & 163.9 & 165.6 & 167.0 & 167.9 & 168.3 & 170.3 & 172.1 & 172.8 & 173.1 \\
17 & 163.3 & 163.8 & 166.1 & 167.2 & 168.4 & 169.4 & 169.7 & 171.0 & 172.9 & 173.7 & 173.7 \\
\hline
\end{tabular}

Sources: [6].

(c)

\begin{tabular}{ccccccccccccc}
\hline \multicolumn{10}{c}{ Differences in mean height of school boys between Jp. and Kr., 1960 to 2010: } \\
using 3 year moving averages (cm) \\
\hline Age/year & 1960 & 1965 & 1970 & 1975 & 1980 & 1985 & 1990 & 1995 & 2000 & 2005 & 2010 \\
\hline 6 & 0.9 & 1.5 & 1.6 & 1.1 & -0.7 & -0.3 & -0.9 & -2.2 & -3.5 & -4.3 & -5.1 \\
12 & 1.8 & 2.9 & 3.2 & 4.2 & 3.2 & 1.9 & 1.8 & 0.0 & -2.0 & -4.3 & -5.6 \\
17 & 1.8 & 2.9 & 1.8 & 1.6 & 1.2 & 0.8 & 0.8 & -0.1 & -2.1 & -2.9 & -3.0 \\
\hline
\end{tabular}

Sources: compiled by the author. 
the earlier period of our investigation may not represent the entire population. That is the reason why this paper focuses on school boys for the comparative analyses of child height between Japan and S. Korea.

The school health surveys in both countries do not cover infants from 1 to 5 years of age and near-adults from 18 to 20 years of age. In the arena of human biology, the first two years of life, or 1000 days, including pregnancy, are crucial periods for future adult height [11] [12] [13] [14]. Analyzing the secular changes in child height in Japan and S. Korea since 1965, [15] states, "Most of the height increment seen in adults had already accrued by age 1.5 years" (p. 12). Thus, the data used here which lack the height development for infants from 1 to 5 years may carry some limitations. On the other hand, the school health surveys in both countries are based on very large nationwide samples conducted every year from 1960 to 2015.

Statistics pertaining to mean height by age groups fluctuate from year to year, particularly in S. Korea, possibly because statistics published in the survey reports depict mean height of school children only in Seoul in some years and averages of a few major districts in other years and also the months when the surveys were conducted may have varied from year to year. In order to smooth the annual fluctuations, we employed 3 year moving averages for all age groups. Table 1 provides secular changes in mean height of school boys in Japan by age (from 6 to 17 years old) in Japan and in S. Korea, by 5 year intervals from 1960 to 2010. With possible statistical errors disregarded, at age 16 - 18 years, school boys in Japan were $3 \mathrm{~cm}$ taller than S. Korean boys in the 1960s and still slightly, say, $1 \mathrm{~cm}$ taller in the 1980s. Japanese boys ceased to grow any taller in the early 1990s and onward, whereas S. Korean boys kept growing in height onward to overtake their Japanese peers by $3 \mathrm{~cm}$ in the mid-2000s and ceased to grow any taller since then.

Based on the statistics pertaining to mean height of children from 1 to 20 years of age, mentioned above, Mori presumed that S. Korean children, in accordance with their ethnic traits, tend to grow faster during their late adolescent years than their Japanese peers [7] [16]. Cole and Mori, however, based on the same data, analyzed by SITAR, concluded that most of the increment in height seen in adults had already accrued by age 1.5 years, either in Japan or S. Korea, as mentioned above. To determine a child growth curve, it is preferable to take the cohort aspects into consideration. A child born in 1960, for example, aged to 11 years old in 1971 and 20 years old in 1980. Using these birth cohorts, the magnitude of growth in height from 6 to 17 years has been nearly constant at 55 $\mathrm{cm}$, almost the same for both Japanese and S. Korean school boys, over the 1960 to 2010 (Figure 1).

To reprise Cole and Mori, most of the height increment seen in senior boys in high school had already accrued by $1^{\text {st }}$ graders in elementary school, age 6 years.

Based on the data provided in Table 1, mean heights of male $1^{\text {st }}$ graders in elementary school in Japan and S. Korea from 1960 to 2010 are compared, to prepare Figure 2, which clearly demonstrates that at age 6 years, Japanese boys 
60.0

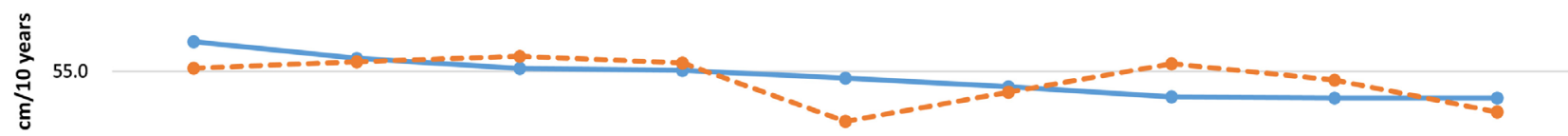

50.0

45.0

40.0

\begin{tabular}{|c|c|c|c|c|c|c|c|c|}
\hline $1960 \lesssim 70$ & $1965 \Longleftrightarrow 75$ & $1970 \nrightarrow 80$ & $1975 \Leftrightarrow 85$ & $1980 \leftrightarrows 90$ & $1985 \nrightarrow 95$ & $1990 \Rightarrow 00$ & $1995 \Longleftrightarrow 05$ & $2000 \rightrightarrows 10$ \\
\hline
\end{tabular}

Figure 1. Changes in height growth velocity from 6 to 17 yr old, by cohorts, Jp. and Kr. school boys, from 1960 to 2010.

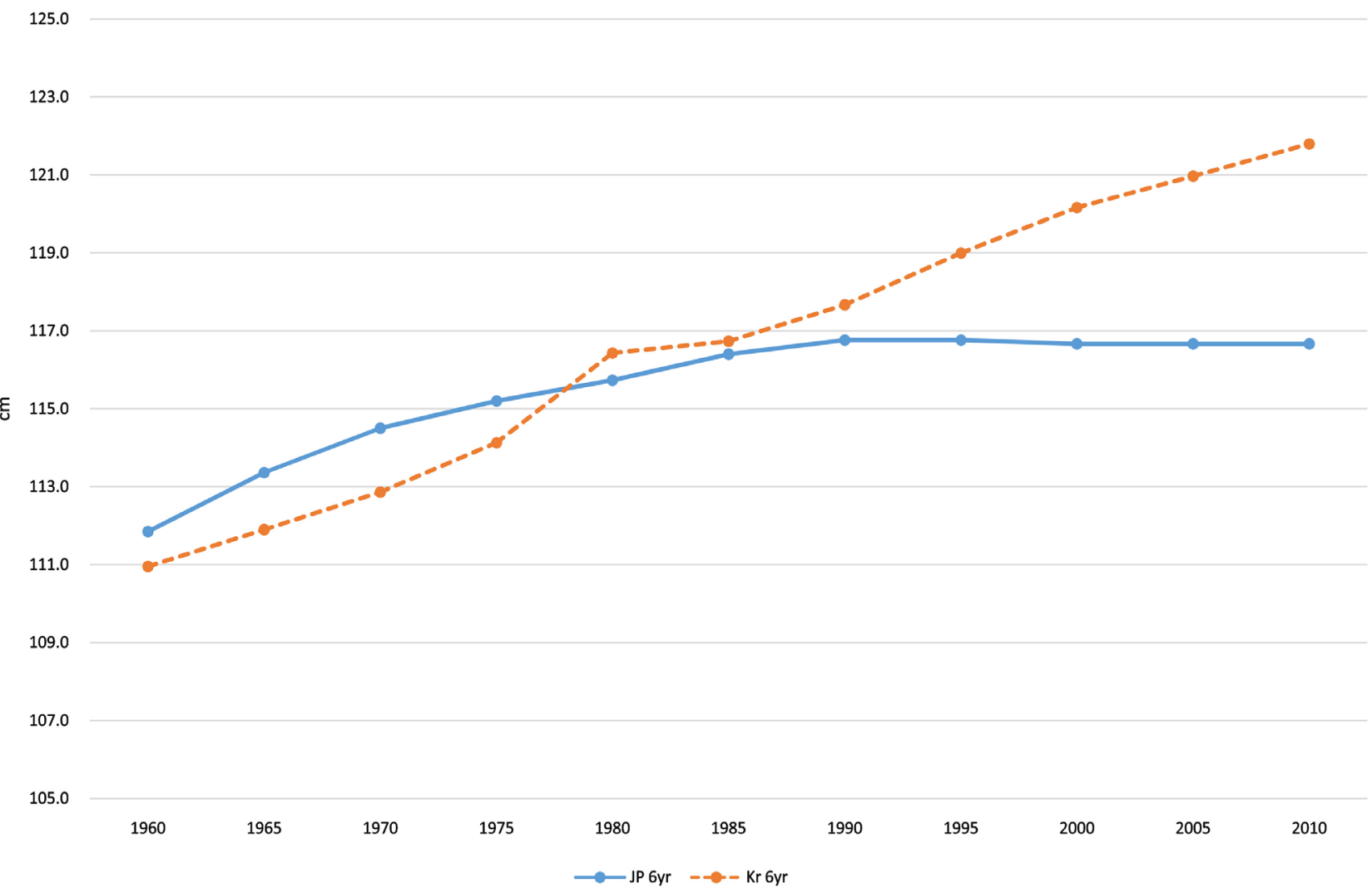

Figure 2. Changes in mean height of 1st graders in elementary school, Jp. and Kr. boys, 1960 to 2000. 
were $112 \mathrm{~cm}$ in 1960 and grew steadily to $115 \mathrm{~cm}$ in $1975,1 \mathrm{~cm}$ taller than Korean boys, and then grew more slowly to $116.8 \mathrm{~cm}$ in 1990 and leveled off afterward, whereas S. Korean boys grew more sharply from $111 \mathrm{~cm}$ in 1960 to $117.7 \mathrm{~cm}, 1 \mathrm{~cm}$ taller than Japanese boys in 1990, and still kept growing afterward to $121.8 \mathrm{~cm}, 5 \mathrm{~cm}$ taller than Japanese boys in 2010 .

\subsection{Food Consumption in Japan and South Korea}

This article will try to explore underlying environmental factors, particularly food supply, ("inputs to health", [1]) which may have given rise to distinct differences in secular changes in child height development between Japan and S. Korea since 1960 presented above.

Culturally, Japanese and Koreans share basically the same dietary patterns, i.e., shushoku (staple foods) and fukushoku (side dishes). Traditionally, they take principal energy from rice, noodles and/or bread with miso-soup and a small amount of okazu (side dishes), composed of fish/meats mixed with large amounts of vegetables in their diet. As their standards of living improved, they first increased both shushoku and fukushokuand then gradually increased fukushoku at the sacrifice of shushoku, rice in particular. This tendency of dietary changes is more pronounced in Japan than in S. Korea: more concretely, per capita net supply of meat + eggs and fish was 63.9 and $71.1 \mathrm{~kg} /$ year, respectively in Japan, as compared to 47.6 and $50.1 \mathrm{~kg} /$ year in S. Korea in 1995, for example, whereas that of cereals was $122.9 \mathrm{~kg} /$ year in Japan, as compared to $168.5 \mathrm{~kg} /$ year in S. Koreain the same year (Table 3). In term of daily individual caloric intakes, S. Korea's have been a few hundred kcal/day greater since the mid-1970s than Japan's (Table 2). Traditionally, Asians do not drink much milk, as compared to

Table 2. Changes in per capita caloric intakes, from vegetal and animal products: Japan and South Korea, 1961 to 2010.

\begin{tabular}{|c|c|c|c|c|c|c|}
\hline & \multicolumn{6}{|c|}{ (kcal/day) } \\
\hline & \multicolumn{2}{|c|}{ Grand Total } & \multicolumn{2}{|c|}{ Vegetal Products } & \multicolumn{2}{|c|}{ Animal Products } \\
\hline & Jp. & $\mathrm{Kr}$. & Jp. & Kr. & Jp. & $\mathrm{Kr}$. \\
\hline 1961 & 2525 & 2141 & 2274 & 2085 & 251 & 56 \\
\hline 1965 & 2620 & 2367 & 2289 & 2293 & 331 & 74 \\
\hline 1970 & 2737 & 2816 & 2314 & 2712 & 423 & 103 \\
\hline 1975 & 2716 & 3106 & 2252 & 2939 & 464 & 167 \\
\hline 1980 & 2798 & 3025 & 2261 & 2812 & 537 & 212 \\
\hline 1985 & 2861 & 2951 & 2281 & 2679 & 580 & 272 \\
\hline 1990 & 2948 & 2956 & 2332 & 2636 & 616 & 320 \\
\hline 1995 & 2920 & 3022 & 2294 & 2609 & 626 & 413 \\
\hline 2000 & 2899 & 3094 & 2296 & 2647 & 604 & 447 \\
\hline 2005 & 2829 & 3102 & 2242 & 2630 & 586 & 472 \\
\hline 2010 & 2685 & 3281 & 2135 & 2746 & 550 & 535 \\
\hline
\end{tabular}

Sources: [4]. 
most Europeans. However, Japanese consumed (in terms of net supply) 86.2 $\mathrm{kg} /$ year of milk in 1995, substantially more than Koreans who consumed 48.8 $\mathrm{kg} /$ year of milk $^{3}$ in the same year (Table 3 ).

On the other hand, S. Koreans have consumed substantially more vegetables than Japanese since the mid-1970s, i.e., per capita net supply of vegetables in S. Korea was $222.3 \mathrm{~kg} /$ year, as compared to $116.6 \mathrm{~kg} /$ year in Japan in 1995, for example. People in Korea did not eat much fruits many years ago. Per capita net supply of fruit in S. Korea was 5.2 and $9.8 \mathrm{~kg} /$ year, respectively in 1961 and 1965, as compared to 29.7 and $39.0 \mathrm{~kg} /$ year, respectively in Japan in the same years. Per capita consumption (=net supply) of fruit in S. Korea steadily increased to $14.6 \mathrm{~kg} /$ year in 1975 and to $69.6 \mathrm{~kg} /$ year in 1995, whereas that in Japan hit the peak in 1975 at $61.9 \mathrm{~kg} /$ year and then gradually declined to $53.2 \mathrm{~kg} /$ year in 1995 (Table 3). As will be discussed in detail in the subsequent section, children and young adults in Japan began to reduce their fruit consumption radically in the mid-1970s. Young people in Japan also reduced their consumption of vegetables, not to the extent of fruit, though.

\section{Discussion}

Comprehensive surveys of daily nutritional intakes, by major food groups, both in terms of $\mathrm{kcal} / \mathrm{capita}$ and grams/capita have been conducted since the end of WW II in Japan, whereas a national health and nutrition survey [21] was first conducted in 1998 in S. Korea, followed by the second one in 2001, and the third one in 2005. In comprehending trends and differences in food consumption between Japan and S. Korea since 1960 onward, official nutrition surveys cannot meet our needs for this paper. This is the reason why we relied on [4] for the basic information concerning changes and differences in food consumption between Japan and S. Korea over the past half century, as presented in the preceding section. Regrettably, however, we used national per capita net food supply (as proxy for consumption) for the entire population, not for the growing children, in particular.

Japan's Nutrition Surveys [18] started to publish per capita food intakes by age groups in 1995 for the first time, while we may need the age-wide data for the period three decades up to 1995.

Japan's Bureau of Statistics has conducted household income and expenditure surveys [22] of approximately 8000 households across the nation, with $1 / 6$ of the subjects replaced each month every year since 1950. [22] publishes the survey results by goods and services, such as rice, --, beef, pork, ---, fresh fruit, coffee, --, gasoline, eating-out, including expenditures for school lunch, at sushi restaurants, etc. in major cities across the country and by income classes of households. Starting in 1971, [22] published expenditures on major goods and services

${ }^{3}$ Per capita net supply (kg/year) of milk, excluding butter, for Republic of Korea seems to be extraordinarily under-calculated, particularly for the period after the mid-1980s, as compared to the estimates provided [19].The author calculated per capita supply of milk, excluding butter in $\mathrm{kg} /$ year by dividing total domestic supply as providedin [4] in 1,000 tons/year by total populationavailable also from [20]. 
Table 3. Changes in per capita net supply of selcetd product groups in Japan and S. Korea, 1961 to 2010 .

\begin{tabular}{|c|c|c|c|c|c|}
\hline & & & & & (kg/year) \\
\hline Cereals & Japan & S. Korea & Meat + Egg & Japan & S. Korea \\
\hline 1961 & 157.8 & 176.8 & 1961 & 16.8 & 5.5 \\
\hline 1965 & 153.3 & 184.6 & 1965 & 24.6 & 7.1 \\
\hline 1970 & 144.3 & 217.8 & 1970 & 34.1 & 9.2 \\
\hline 1975 & 142.4 & 235.3 & 1975 & 39.2 & 11.8 \\
\hline 1980 & 134.2 & 199.3 & 1980 & 46.7 & 19.7 \\
\hline 1985 & 133.3 & 190.7 & 1985 & 50.8 & 25.5 \\
\hline 1990 & 129.5 & 168.6 & 1990 & 57.3 & 33.7 \\
\hline 1995 & 122.9 & 168.5 & 1995 & 63.9 & 47.6 \\
\hline 2000 & 120.4 & 160.3 & 2000 & 64.8 & 57.3 \\
\hline 2005 & 115.1 & 146.1 & 2005 & 65.9 & 59.9 \\
\hline 2010 & 111.2 & 149.0 & 2010 & 66.7 & 70.1 \\
\hline Vegetable & Japan & S. Korea & Milk $^{*}$ & Japan & S. Korea \\
\hline 1961 & 96.8 & 75.7 & 1961 & 26.2 & 0.7 \\
\hline 1965 & 119.6 & 82.3 & 1965 & 40.7 & 3.4 \\
\hline 1970 & 126.8 & 104.0 & 1970 & 53.5 & 3.8 \\
\hline 1975 & 121.3 & 147.7 & 1975 & 53.6 & 5.3 \\
\hline 1980 & 122.6 & 197.9 & 1980 & 73.7 & 12.9 \\
\hline 1985 & 119.5 & 181.7 & 1985 & 79.1 & 25.8 \\
\hline 1990 & 116.7 & 200.6 & 1990 & 81.8 & 42.1 \\
\hline 1995 & 116.6 & 222.3 & 1995 & 86.2 & 48.8 \\
\hline 2000 & 112.8 & 235.7 & 2000 & 84.0 & 54.0 \\
\hline 2005 & 107.8 & 215.8 & 2005 & 79.9 & 54.9 \\
\hline 2010 & 98.9 & 196.5 & 2010 & 74.0 & 52.8 \\
\hline Fruit & Japan & S. Korea & Fish & Japan & S. Korea \\
\hline 1961 & 29.7 & 5.2 & 1961 & 50.7 & 13.2 \\
\hline 1965 & 39.0 & 9.8 & 1965 & 51.6 & 17.6 \\
\hline 1970 & 53.9 & 12.3 & 1970 & 60.2 & 18.4 \\
\hline 1975 & 61.9 & 14.6 & 1975 & 66.6 & 39.0 \\
\hline 1980 & 55.6 & 23.2 & 1980 & 65.0 & 41.3 \\
\hline 1985 & 51.9 & 35.2 & 1985 & 69.7 & 47.3 \\
\hline 1990 & 50.2 & 47.0 & 1990 & 71.4 & 46.4 \\
\hline 1995 & 53.2 & 69.6 & 1995 & 71.1 & 50.1 \\
\hline 2000 & 51.4 & 69.6 & 2000 & 67.3 & 46.9 \\
\hline 2005 & 60.3 & 76.1 & 2005 & 60.4 & 53.8 \\
\hline 2010 & 49.1 & 67.6 & 2010 & 52.6 & 56.7 \\
\hline
\end{tabular}

Sources: [4]. Note: *Derived by total domestic supply/population, provided in [20]. 
(prices paid and quantities, in the case of goods) by age groups of household head $(\mathrm{HH})$. In the case of foods, eating-out has been on the increase lately and thus [22] does not cover most of the actual consumption of selected food items. In the case of meat, for example, FIES is estimated to cover about half of total meat consumption [23], $60 \%-80 \%$ of fresh fruit [24], and $50 \%-60 \%$ of vegetables [25].

Focusing just on at-home consumption of selected food products, individual consumption by age groups can be derived from [22] data classified by $\mathrm{HH}$ age groups, by means of the TMI model which explicitly incorporates family age composition by $\mathrm{HH}$ age groups [26].

M. Blum states, "The central determinants of human stature is the protein-intensity of a nation's diet. Populations consuming larger amounts of animal protein reach higher average height levels than countries with less animal protein consumption. However, a high consumption of animal proteins alone does not result in increasing body heights if the overall consumption of calories and other essential nutrients is insufficient" [2], p. 21). The author is inclined to contend that this may apply to the comparative case of child height developments between Japan and S. Korea over the past half century since the early 1960s. Ishibashi, based on the comprehensive analyses of large samples of [22] panel data since the early 1980s, Japanese youth have been consuming more meats than the older adults [27] [28]. In Japan, vegetables are believed to regulate bowel movements and fruit is called mizikashi (jelly desert), implying fruit consumption has nothing to do with essential nutrients. The author, however, suspects that children in Japan consumed insufficient "essential nutrients" noted by M. Blum, due to the drastically reduced consumption of fruit and vegetables ${ }^{4}$ in the recent few decades.

[29], Ministry of Agriculture drew public attention to the widespread tendencies of wakamono no kudamono-banare (steering away from fruit by the young), in the 1980s and the early 1990s by displaying household fresh fruit purchases classified by $\mathrm{HH}$ age groups divided simply by the number of persons contained in each group. [30] designed a quadratic programming model to derive individual at-home consumption of selected food products by age from FIES, classified by $\mathrm{HH}$ age groups, which was statistically refined by [26].

Table 4 and Table 5 demonstrate that Japanese youth used to eat as much fruit and vegetables as older adults in the early 1970s but began to reduce their consumption of these products in the early 1980s, while the older adults kept constant their produce consumption at high levels: for example, nearly three times higher than young people's consumption in the case of vegetables and more than five times in the case of fruit in 2000.

\footnotetext{
${ }^{4} \mathrm{~A}$ few recent empirical studies report that consumption of fruit and vegetables contributes to greater bone mineral accrual/density in post-menopausal females [31] [32] and also in young and adolescent children [33] [34] [35] [36]. As shown in Appendix Table 1, S. Korean youth in their 20s and 30 s consume as much vegetables and fruit as the older adults in the end of 1990s and the early 2000s [37]. In the presence of robust cohort effects in food consumption [38] [39], S. Korean children are supposed to consume as much vegetables and fruit as adults in the 1980s and 1990s.
} 
Table 4. Changes in per capita at-home consumption of fresh fruit by age groups, 1971 to 2010 in Japan.

\begin{tabular}{cccccccc}
\hline Age/year & 1971 & 1980 & $1985-86$ & 1990 & $1995-96$ & 2000 & 2010 \\
\hline $0-9$ yo & 36.3 & 26.5 & 15.2 & 8.9 & 4.7 & 2.3 & 2.4 \\
$10-19$ & 45.6 & 30.5 & 20.1 & 14.9 & 9.4 & 5.7 & 4.4 \\
$20-29$ & 48.3 & 31.5 & 23.4 & 16.8 & 15.1 & 11.8 & 9.8 \\
$30-39$ & 46.1 & 43.8 & 36.6 & 30.4 & 23.6 & 21.8 & 14.8 \\
$40-49$ & 51.0 & 52.6 & 48.5 & 44.9 & 37.2 & 33.4 & 20.5 \\
$50-59$ & 54.4 & 59.9 & 56.6 & 54.0 & 50.5 & 48.5 & 32.1 \\
$60-69$ & 44.5 & 58.5 & 61.1 & 62.0 & 58.7 & 60.7 & 53.3 \\
$70+$ & 41.2 & 54.2 & 59.6 & 60.3 & 62.1 & 65.8 & 58.8 \\
Grand ave. & 45.6 & 41.6 & 36.4 & 33.8 & 31.5 & 31.1 & 27.7 \\
\hline
\end{tabular}

Sources: derived from [22] by the authors, using the TMI model. Notes: Estimated by 5 year age intervals first, which were simply averaged into 10 year intervals.

Table 5. Changes in per capita at-home consumption of fresh vegetables by age groups, 1971 to 2010 in Japan.

\begin{tabular}{cccccccc}
\hline Age/year & 1971 & 1980 & $1985-86$ & 1990 & $1995-96$ & 2000 & 2010 \\
\hline $0-9$ yo & 44.8 & 33.7 & 27.3 & 23.0 & 20.2 & 18.3 & 17.5 \\
$10-19$ & 62.2 & 51.1 & 44.7 & 38.8 & 36.0 & 30.0 & 30.6 \\
$20-29$ & 67.8 & 56.1 & 52.5 & 45.5 & 46.2 & 40.8 & 37.6 \\
$30-39$ & 68.5 & 65.6 & 60.2 & 54.3 & 52.3 & 49.8 & 45.7 \\
$40-49$ & 77.4 & 80.3 & 78.2 & 71.7 & 67.3 & 62.0 & 54.7 \\
$50-59$ & 89.0 & 90.5 & 91.9 & 84.0 & 83.7 & 82.3 & 66.2 \\
$60-69$ & 87.5 & 93.3 & 99.0 & 91.2 & 91.0 & 94.0 & 80.8 \\
$70+$ & 71.0 & 80.0 & 89.4 & 80.1 & 81.3 & 86.9 & 81.5 \\
Grand ave. & 67.1 & 63.6 & 62.4 & 58.3 & 59.0 & 57.2 & 55.4 \\
\hline
\end{tabular}

Sources: the same as Table 4. Notes: the same as Table 4.

\section{Conclusions and Future Research Recommendations}

At age 17 - 18 years, Japanese school boys were $2-3 \mathrm{~cm}$ taller in mean height in the 1960s through 1970s, barely $1 \mathrm{~cm}$ taller in the 1980s than their Korean peers and they ceased to grow any taller in and around 1990, whereas Korean boys kept steadily growing in height to overtake their Japanese peers by $3 \mathrm{~cm}$ in the mid-2000s and ceased to grow any taller since then.

After the end of WW II, Japan and South Korea made rapid and steady economic progress, with S. Korea some two decades behind Japan due to the Korean War (1950-53). As the economy grew, food consumption remarkably improved both in quantity and quality. Particularly, intake of animal-sourced products increased conspicuously in the two countries. Yet, animal product supply per person in Japan was considerably greater, as much as $30 \%$ higher, than S. Korea in the mid-1990s.

Increases in animal protein products alone cannot explain the differences in 
growth patterns of child height between the two countries. However, S. Koreans have been eating twice as many vegetables as Japanese on average and their per capita fruit consumption soared very rapidly since the mid-1970s, surpassing that of Japanese in the mid-1990s. Meanwhile, Japanese youth reduced their fruit and vegetable consumption from the mid-1970s on. This "steering away from fruit and vegetables" by Japanese youth could have contributed to the stagnation of child height growth since the early 1990s, and deserves scientific investigation.

\section{Acknowledgements}

The author is grateful to John Dyck, formerly an economist in Asian affairs at ERS, USDA, who advised to rearrange the structure of the article and thoroughly edited the manuscript. Thanks go to anonymous reviewers for considerate comments and careful proofs.

\section{Research Funding}

No research fund has been received from any sources.

\section{Conflicts of Interest}

The author declares no conflict of interest.

\section{References}

[1] Steckel, R.H. (1995) Statue and the Standard of Living. Journal of Economic Literature, XXXIII, 1903-1940.

[2] Blum, M. (2013) Cultural and Genetic Influences on the "Biological Standard of Living". Historical Method, 46, 19-30. https://doi.org/10.1080/01615440.2012.703952

[3] Federal Research Bank of St. Louis. Federal Reserve Economic Data, Downloaded from Internet.

[4] FAO of the United Nations. FAOSTAT, Food Balance Sheets, Various Issues on Line.

[5] Japanese Government, Ministry of Education, School Health Examination Statistics Survey, Various Issues, Tokyo.

[6] Republic of Korea, Department of Education, Center for Educational Statistics. Statistical Yearbook of Education, Various Issues, Seoul.

[7] Mori, H. (2017) Stature: Key Determinants of Positive Height Trends-The Cases of Japan and South Korea. The Monthly Bulletin of Social Science, No. 644, 21-40.

[8] (2018) Why Koreans Became Taller than Japanese. Annual Bulletin of Social Science, No. 52, 177-195.

[9] Kim, Y.S. (1982) Growth Status of Korean Children in Japan. Annals of Human Biology, 9, 453-458. https://doi.org/10.1080/03014468200005981

[10] Kim, H.-K. (2014) Comparative Studies of Education Societies in Japan and South Korea. Ph.D. Dissertation, Hosei University, Tokyo. (In Japanese)

[11] Cole, T.J. (2003) The Secular Trend in Human Physical Growth: A Biological View. Economics and Human Biology, 1, 161-168. https://doi.org/10.1016/S1570-677X(02)00033-3 
[12] Deaton, A. (2007) Height, Health, and Development. PNAS, 104, 13232-13237. https://doi.org/10.1073/pnas.0611500104

[13] Prentice, A.K., Ward, et al. (2013) Critical Windows for Nutritional Intervenions against Stuntings. The American Journal of Clinical Nutrition, 83, 1420-1428.

[14] Headey, D., Hirvonen, K. and Hoddinott, J. (2018) Animal Sourced Foods and Child Stunting. American Journal of Agricultural Economics, 100, 1302-1319.

[15] Cole, T.J. and Mori, H. (2017) Fifty Years of Child Height and Weight in Japan and South Korea: Contrasting Secular Trend Patterns Analyzed by SITAR. American Journal of Human Biology, 30.

[16] Mori, H. (2016) Secular Changes in Body Height and Weight of Population in Japan since the End of WW II in Comparison with South Korea. The Monthly Bulletin of Social Science, No. 636, 13-25.

[17] Kim, J.-Y., Choi, J.-M., Jin-Soo, M., Shin, S.-H., et al. (2008) Anthropometric Changes in Children and Adolescents from 1965 to 2005 in Korea. American Journal of Physical Anthropology, 136, 230-236. https://doi.org/10.1002/ajpa.20801

[18] Japanese Government, Ministry of Health, Labor and Welfare. National Nutrition Examination Survey, Various Issues, Tokyo.

[19] Republic of Korea, Department of Food and Agriculture. Food Balance Sheets, Various Issues.

[20] FAOSTAT. Population, Various Issues on Line.

[21] Republic of Korea, Korea Centers for Disease Control and Prevention. Korean National Health and Nutrition Examination Surveys.

[22] Japanese Government, Ministry of General Affairs, Bureau of Statistics. Family Income and Expenditure Survey (FIES), Various Issues, Tokyo.

[23] Ministry of Agriculture, Forestry and Fisheries, Division of Meat and Eggs, Various Years, Tokyo.

[24] Mori, H., Clason, D.L., Ishibashi, K., Gorman, W.D. and Dyck, J. (2009) Declining Orange Consumption in Japan-Generational Changes or Something Else? Economic Research Report, No. 71, 23.

[25] Kobayashi, S. (2006) The Trend of Vegetable Demand by Intended Purposes and the Main Issues of Domestic Production. Journal of Agricultural Policy Research, 11, 1-27. (In Japanese)

[26] Tanaka, M., Mori, H. and Inaba, T. (2004) Re-Estimating per Capita Individual Consumption by Age from Household Data. Japanese Journal of Rural Economics, 6, 20-30. https://doi.org/10.18480/jjre.6.20

[27] Ishibashi, K. (2006) Statistical Investigations of Structural Changes in Household Consumption: Household Categories and Age Factors. National Research Center for Agricultural Research, Tsukuba, 57. (In Japanese)

[28] (2007) Trends in Food Consumption Structure. Long-Term Finance, 99, Agriculture and Fisheries Finance Corporation, Tokyo. (In Japanese)

[29] Japanese Government, Ministry of Agriculture, Forestry and Fisheries (1995) White Paper on Agriculture 1994, Tokyo.

[30] Mori, H. and Inaba, T. (1997) Estimating Individual Fresh Fruit Consumption by Age from Household Data, 1979 to 1994. Journal of Rural Economics, 69, 175-185.

[31] Sugiura, M., Nakamura, M., Ogawa, K., Ikoma, Y. and Yano, M. (2012) High Serum Carotenoids Associated with Lower Risk for Bone Loss and Osteoporosis in Post-Menopausal Japanese Female Subjects: Prospective Cohort Study. PLoS ONE, 
7, 1-9.

[32] Nakamura, M., Sugiura, M., et al. (2016) Serum $\beta$-Carotene Derived from Satsuma Mandarin and Brachial-Ankle Pulse Wave Velocity: The Mikkabi Cohort Study. Nutrition, Metabolism \& Cardiovascular Diseases, 26, 808-814. https://doi.org/10.1016/j.numecd.2016.04.001

[33] McGartland, C.P., Robson, P.J., et al. (2004) Fruit and Vegetable Consumption and Bone Mineral Density: Northern Ireland Young Hearts Project. The American Journal of Clinical Nutrition, 80, 1019-1023. https://doi.org/10.1093/ajcn/80.4.1019

[34] Vatanparast, H., Baxter-Jones, A., Faulkner, R.A., Bailey, D.A. and Whiting, S.J. (2005) Positive Effect of Vegetable and Fruit Consumption and Calcium Intake on Bone Mineral Accrual in Boys during Growth from Childhood to Adolescence: The University of Saskatchewan Pediatric Bone Mineral Accrual Study. The American Journal of Clinical Nutrition, 82, 700-706. https://doi.org/10.1093/ajcn/82.3.700

[35] Prynne, C.J., Mishra, G.D., et al. (2006) Fruit and Vegetable Intakes and Bone Mineral Statues: A Cross Sectional Study in 5 Age and Sex Cohorts. The American Journal of Clinical Nutrition, 83, 1420-1428. https://doi.org/10.1093/ajcn/83.6.1420

[36] Li, J.-J., Huang, Z.-W., et al. (2012) Fruit and Vegetable Intake and Bone Mass in Chinese Adolescents, Young and Postmenopausal Women. Public Health Nutrition, 16, 78-86. https://doi.org/10.1017/S1368980012001127

[37] Park, J. (2018) Dept. of Nutrition, Gachon University, Courtesy.

[38] Mori, H. and Saegusa, Y. (2010) Cohort Effects in Food Consumption: What They Are and How They Are Formed. Evolutionary and Institutional Economics Review, 7, 43-63. https://doi.org/10.14441/eier.7.43

[39] Mori, H., Inaba, T. and Dyck, J. (2016) Accounting for Structural Changes in Demand for Foods in the Presence of Age and Cohort Effects: The Case of Fresh Fish in Japan. Evolutionary and Institutional Economics Review, 13, 363-379. 


\section{Appendix}

Table A1. Per capita daily intakes of fruits and vegetables by age groups in South Korea, 1998 and 2001.

\begin{tabular}{|c|c|c|c|c|}
\hline \multicolumn{3}{|c|}{ (1) 1 - 6 years old infants } & & \multirow[t]{2}{*}{ (gr/day) } \\
\hline \multirow{2}{*}{ Food groups } & \multicolumn{2}{|c|}{1998} & 2001 & \\
\hline & $\mathrm{g}$ & SE & $\mathrm{g}$ & SE \\
\hline Fruits & 167.9 & 10.0 & 179.6 & 9.1 \\
\hline Vegetables & 81.6 & 4.1 & 85.1 & 3.8 \\
\hline \multicolumn{3}{|c|}{ (2) 7 - 14 years old children } & & (gr/day) \\
\hline \multirow{2}{*}{ Food groups } & \multicolumn{2}{|c|}{1998} & \multicolumn{2}{|c|}{2001} \\
\hline & $\mathrm{g}$ & SE & $\mathrm{g}$ & SE \\
\hline Fruits & 201.9 & 10.4 & 197.7 & 9.7 \\
\hline Vegetables & 190.6 & 7.0 & 183.1 & 4.6 \\
\hline \multicolumn{3}{|c|}{ (3) 15 - 19 years old adolescents } & & (gr/day) \\
\hline \multirow{2}{*}{ Food groups } & \multicolumn{2}{|c|}{1998} & \multicolumn{2}{|c|}{2001} \\
\hline & g & SE & g & SE \\
\hline Fruits & 192.2 & 13.7 & 169.6 & 13.1 \\
\hline Vegetables & 227.8 & 6.0 & 234.2 & 7.1 \\
\hline \multicolumn{3}{|c|}{ (4) 20 - 29 years old adults } & & (gr/day) \\
\hline \multirow{2}{*}{ Food groups } & \multicolumn{2}{|c|}{1998} & \multicolumn{2}{|c|}{2001} \\
\hline & g & SE & $\mathrm{g}$ & SE \\
\hline Fruits & 220.4 & 11.4 & 208.6 & 12.1 \\
\hline Vegetables & 299.8 & 6.8 & 297.0 & 6.7 \\
\hline \multicolumn{3}{|c|}{ (5) 30 - 39 years old adults } & & (gr/day) \\
\hline \multirow{2}{*}{ Food groups } & \multicolumn{2}{|c|}{1998} & \multicolumn{2}{|c|}{2001} \\
\hline & $\mathrm{g}$ & SE & $\mathrm{g}$ & SE \\
\hline Fruits & 228.8 & 9.8 & 227.0 & 10.4 \\
\hline Vegetables & 345.5 & 6.5 & 361.7 & 7.1 \\
\hline \multicolumn{3}{|c|}{ (6) 40 - 49 years old adults } & & (gr/day) \\
\hline \multirow{2}{*}{ Food groups } & \multicolumn{2}{|c|}{1998} & \multicolumn{2}{|c|}{2001} \\
\hline & g & SE & g & SE \\
\hline Fruits & 202.9 & 8.5 & 222.4 & 12.4 \\
\hline Vegetables & 360.6 & 9.4 & 369.1 & 7.8 \\
\hline \multicolumn{3}{|c|}{ (7) 50 - 59 years old adults } & & (gr/day) \\
\hline \multirow{2}{*}{ Food groups } & & & & \\
\hline & g & SE & g & SE \\
\hline Fruits & 189.7 & 11.2 & 235.4 & 12.6 \\
\hline Vegetables & 337.5 & 7.9 & 349.1 & 8.8 \\
\hline (8) & rs old ad & & & (gr/day) \\
\hline Fond arouns & & & & \\
\hline 100त givaps & $\mathrm{g}$ & SE & $\mathrm{g}$ & SE \\
\hline Fruits & 158.6 & 11.6 & 210.2 & 14.1 \\
\hline Vegetables & 306.6 & 8.4 & 355.9 & 10.1 \\
\hline
\end{tabular}

